А. Д. Беденюк, В. В. Мальований, В. Б. Доброродній, Л. Є. Війтович

ДВНЗ “Тернопільський державний медичний університет імені І. Я. Горбачевського МОЗ України"

\title{
ЕТАПИ ПРАКТИЧНОЇ ПІДГОТОВКИ СТУДЕНТІВ НА КАФЕДРІ ХІРУРГІЇ № 13 УРОЛОГІЄЮ, МАЛОІНВАЗИВНОЮ ХІРУРГІЄЮ ТА НЕЙРОХІРУРГІЄЮ ІМЕНІ ПРОФЕСОРА Л. Я. КОВАЛЬЧУКА
}

\author{
A. D. Bedenyuk, V. V. Malovanyy, V. B. Dobrorodniy, L. E. Viytovych \\ I. Horbachevsky Ternopil State Medical University \\ STAGES OF THE PRACTICAL TRAINING OF STUDENTS AT THE \\ DEPARTMENT OF SURGERY NO. 1 WITH UROLOGY, MINIMALLY \\ INVASIVE SURGERY AND NEUROSURGERY NAMED AFTER \\ PROFESSOR L. KOVALCHUK
}

\begin{abstract}
Мета роботи - акцентувати увагу на етапності практичної підготовки студентів на кафедрі хірургії.
Основна частина. Належне оволодіння фундаментальними клінічними знаннями на одному етапі впливає на формування комплексного бачення проблеми на наступних. На кафедрі хірургії № 1 з урологією, малоінвазивною хірургією та нейрохірургією імені професора Л. Я. Ковальчука ДВНЗ “Тернопільський державний медичний університет імені І. Я. Горбачевського MO3 України” практичні заняття включають оволодіння студентами спеціальними навичками обстеження, постановки діагнозу та визначення лікувальної тактики у хворих з різною хірургічною патологією на основі отриманих теоретичних знань. Студенти мають змогу оволодіти практичними навичками поетапно, відповідно до рівня складності, що сприяє поліпшенню розуміння та засвоєння матеріалу, розвитку клінічного мислення та навиків.

Висновки. Етапність практичної підготовки студентів на кафедрі хірургії дозволила підвищити ефективність навчального процесу. Студенти мають змогу оволодіти практичними навичками синхронно з отриманими теоретичними знаннями, що сприяє поліпшенню розуміння та комплексному засвоєнню матеріалу, розвитку клінічного мислення та навиків.
\end{abstract}

Ключові слова: практична підготовка; навчальна програма; матрикул практичних навичок.

The aim of the work - to emphasize the staging of practical training of students at the Department of Surgery.

The main body. Proper mastering of fundamental clinical knowledge at one stage affects the formation of a complex vision of the problem at the next stages.

At the Department of Surgery No. 1 of Urology, Neurosurgery and Minimally Invasive Surgery named after Professor L. Kovalchuk of I. Horbachevsky Ternopil State Medical University practical classes include mastering by students the special skills of examination, diagnosis and determination of treatment tactics in patients with different surgical pathologies based on the obtained theoretical knowledge. Students can master practical skills in a step-by-step manner, according to the level of complexity, which contributes to improved understanding and assimilation of material, the development of clinical thinking and skills.

Conclusions. The staging of practical training of students at the Department of Surgery made it possible to improve the efficiency of the educational process. Students have the opportunity to learn practical skills synchronously with the theoretical knowledge that promotes better understanding and comprehensive study of material, development of clinical thinking and skills.

Key words: practical training; curriculum; matricula of practical skills.

Вступ. Навчання в університеті є найважливішим періодом для формування клінічного мислення, важливих навичок та підходів до лікувального процесу і може вплинути на подальшу клінічну компетенцію серед практикуючих лікарів [1-3]. Належне оволодіння фундаментальними клінічними знаннями на одному етапі впливає на формування комплексного бачення проблеми на наступних $[4,5]$.
Мета роботи - акцентувати увагу на етапності практичної підготовки студентів на кафедрі хірургії.

Основна частина. Програма виконання практичної частини заняття на кафедрі хірургї̈ № 1 з урологією, малоінвазивною хірургією та нейрохірургією імені професора Л. Я. Ковальчука включає курацію хворого з патологією по одній з тем заняття; участь в інструментальних і апаратних методах

(ㄱ А. Д. Беденюк, В. В. Мальований, В. Б. Доброродній, Л. Є. Війтович 
обстеження одного із пацієнтів відділення за темою заняття (рентгенографія або ендоскопія, ультразвукове дослідження, комп’ютерна томографія та ін.), а також участь у діагностично-лікувальних процедурах (перев'язки, пункції, інгаляції, налагодження аспіраційної системи, постановка зонда, сечового катетера та інших маніпуляцій, присутність під час виконання операції та ін.). Протягом заняття викладач приймає практичні навички, що включені в матрикулярну книжку (матрикул практичних навичок - це перелік практичних навичок, який складений кафедрою на основі галузевих стандартів освіти і є обов'язковим для опанування студентами протягом навчального року [6]) та відповідають темі заняття. Практичні навички мають бути засвоєні студентом не нижче четвертого рівня, що вимагає проведення маніпуляції (діагностичної чи лікувальної процедури) або курації хворого під контролем викладача.

Зокрема на четвертому курсі метою занять $є$ набуття студентами навичок збору скарг та анамнезу захворювання у пацієнтів з гострою хірургічною патологією, килами, гострою затримкою сечі та сечокам'яною хворобою, клінічного обстеження огляду хворого, пальпації, перкусії, аускультації, а також вміння правильно документувати ці обстеження. До студентів на даному етапі ставляться такі вимоги: правильна техніка і послідовність застосування методів клінічного обстеження, з акцентом на визначення симптомів гострої хірургічної абдомінальної патології та симптомів подразнення очеревини, вміння проводити інтерпретацію нормальних результатів обстеження та проводити виявлення відхилень від норми, виставлення клінічного діагнозу, диференційна діагностика гострої патології органів черевної порожнини, кил, сечокам'яної хвороби, гострої затримки сечі, вміння постановки сечового катетера під наглядом викладача.

На кафедрі хірургії № 13 урологією, малоінвазивною хірургією та нейрохірургією імені професора Л. Я. Ковальчука ТДМУ практичні заняття п’ятикурсників включають курацію реального пацієнта з травмою грудної клітки, деструктивними захворюваннями легень та плеври, варикозним роширенням вен нижніх кінцівок, флебітом та тромбофлебітом, що передбачає збір скарг, анамнезу, проведення об'єктивного обстеження, постановку діагнозу та визначення тактики лікування. Крім вмінь, отриманих на попередньому курсі, студент повинен сформулювати заключний діагноз по конкретній нозології, визначити тактику лікування та заповнити листок призначень пацієнта, визначати тактику ведення післяопераціного періоду, призначати необхідне лікування, демонструвати вміння виконувати необхідні медичні маніпуляції.

Шестикурсники проводять курацію хворих із шлунково-кишковими кровотечами, патологією прямої кишки, нагнійними процесами легень та плеври, хворих на облітеруючі захворювання судин нижніх кінцівок, перитоніт, гострий панкреатит, гостру кишкову непрохідність, демонструючи увесь спектр отриманих на попередніх курсах знань та вмінь: визначати найбільш поширені клінічні симптоми і синдроми в клініці хірургічних хвороб, діагностувати та надавати медичну допомогу при невідкладних станах у клініці хірургічних хвороб, володіти морально-деонтологічними принципами медичного фахівця та принципами фахової субординації у хірургії, трактувати загальні принципи лікування, реабілітації і профілактики найбільш поширених хірургічних захворювань, здійснювати прогноз життя та працездатності при найбільш поширених хірургічних захворюваннях, визначати основні етіологічні та патогенетичні фактори найбільш поширених хірургічних захворювань, класифікувати й аналізувати типову клінічну картину найбільш поширених хірургічних захворювань, складати план обстеження та аналізувати дані лабораторних та інструментальних обстежень при типовому перебігу найбільш поширених хірургічних захворювань, визначати показання та протипоказання до оперативних втручань у плановій та ургентній абдомінальній хірургії, визначати тактику ведення післяопераціного періоду, призначати необхідне лікування, демонструвати вміння виконувати необхідні медичні маніпуляції.

Висновки. Етапність практичної підготовки студентів на кафедрі хірургії дозволила підвищити ефективність навчального процесу. Студенти мають змогу оволодіти практичними навичками синхронно з отриманими теоретичними знаннями, що сприяє поліпшенню розуміння та комплексному засвоєнню матеріалу, розвитку клінічного мислення та навиків. 


\section{Список літератури}

1. Ковальчук Л. Я. Результати реалізації концепції розвитку Тернопільського державного медичного університету імені І. Я. Горбачевського на шляху його входження у світовий освітній простір / Л. Я. Ковальчук // Медична освіта. - 2011. - № 2. - С. 12-20.

2. Promoting fundamental clinical skills: A competencybased college approach at the University of Washington / E. A. Goldstein, C. F. MacLaren, Sh. Smith [et al.] // Academic Medicine. - 2005. - Vol. 80, No. 5. - P. 423-433.

3. Harden R. M. What is a spiral curriculum? / R. M. Harden, N. Stamper // Med. Teacher. - 2009. - Vol. 21. - P. 141-143.

\section{References}

1. Kovalchuk, L.Ya. (2011). Rezultaty realizatsii kontseptsii rozvytku Ternopilskoho derzhavnoho medychnoho universytetu im. I.Ya. Horbachevskoho na shliakhu yoho vkhodzhennia u svitovyi osvitnii prostir [The results of the implementation of the concept of the development of I. Horbachevsky Ternopil State Medical University on the way of its entrance into the world educational space]. Medychna osvita - Medical Education, 2, 12-20 [in Ukrainian].

2. Goldstein, E.A., MacLaren, C.F., Smith, Sh., Mengert, T.J., \& Maestas, R.R. (2005). Promoting fundamental clinical skills: A competency-based college approach at the University of Washington. Academic Medicine, 80 (5), 423-433.

3. Harden, R.M., \& Stamper, N. (2009). What is a spiral curriculum? Med. Teacher, 21, 141-143.
4. Issenberg S. B. Clinical skills training-practice makes perfect / S. B Issenberg, W. C McGaghie // Medical education. - 2002. - Vol. 10, No. 2. - P. 32-39.

5. Tolsgaard M. G. Practical trials in medical education: linking theory, practice and decision making / M. G. Tolsgaard, K. M. Kulasegaram, Ch. Ringsted // Medical Education. - 2017. - Vol. 51, No. 1. - P. 22-30.

6. Мисула I. Р. Про впровадження у навчальний процес ліній практичних навичок (матрикулів) / I. Р. Мисула, О. Є. Федорців // Медична освіта. - 2007. - № 2. C. $30-32$.

4. Issenberg, S.B., \& McGaghie, W.C. (2002). Clinical skills training-practice makes perfect. Medical Education, 10 (2), 32-39.

5. Tolsgaard, M.G., Kulasegaram, K.M., \& Ringsted, Ch. (2017). Practical trials in medical education: linking theory, practice and decision making. Medical Education, 51 (1), 22-30.

6. Mysula, I.R., \& Fedortsiv, O.Ye. (2007). Pro vprovadzhennia u navchalnyi protses linii praktychnykh navychok (matrykuliv) [Introduction of practical skills (matricula) in the educational process]. Medychna osvitaMedical Education, 2, 30-32 [in Ukrainian].

Отримано 03.07.18 